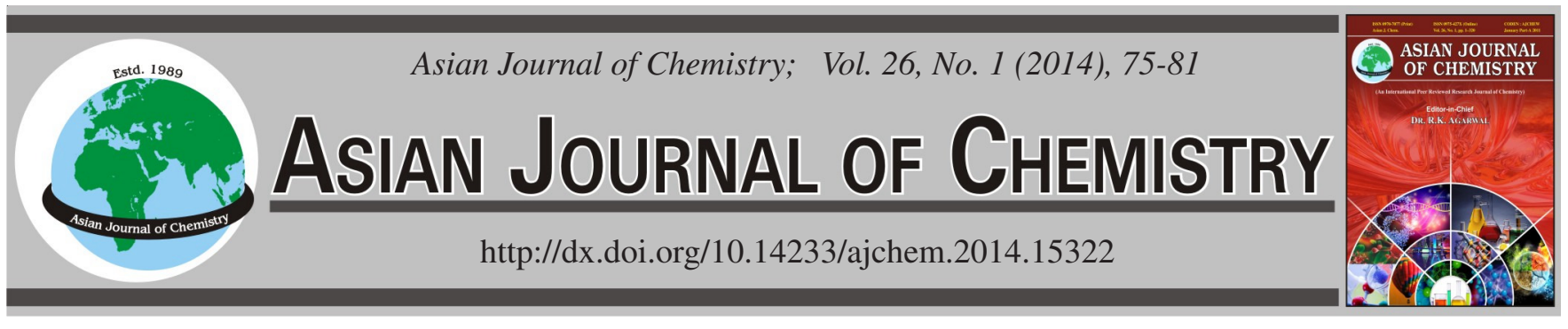

\title{
Biosorption of Malachite Green Dye onto Araucaria cookii Bark: Optimization Using Response Surface Methodology
}

\author{
P. KALPANA ${ }^{1, *}$ and P. KING ${ }^{2}$
}

${ }^{1}$ Department of Chemical Engineering, GMR Institute of Technology, Rajam-532 127, India

${ }^{2}$ Department of Chemical Engineering, Andhra University, Visakhapatnam-530 003, India

*Corresponding author: E-mail: kalpanamtech@yahoo.com

\begin{abstract}
Araucaria cookii bark has been studied as low cost, easily available natural biosorbent for removal of malachite green from aqueous solution. The influence of operating parameters such as contact time, $\mathrm{pH}$, temperature, adsorbent dosage and initial dye concentration on the sorption of malachite green were analyzed using response surface methodology. The proposed quadratic model of central composite design fitted so well to the experimental data that it could be used to navigate the design space according to the results of the analysis of variance. The optimum sorption conditions were determined. Characterization of the biosorbent was performed using scanning electron microscopy and Fourier transform infrared spectroscopy. Equilibrium isotherms were analyzed by the Langmuir, Freundlich and Tempkin isotherm models. Dye biosorption equilibrium data fitted well to the Freundlich isotherm rather than the others. The kinetic studies for malachite green biosorption showed rapid sorption dynamics by a pseudo second order kinetic model. Thermodynamic studies showed that malachite green biosorption onto Araucaria cookii bark was mainly a spontaneous and exothermic process.
\end{abstract}

Keywords: Response surface methodology, Araucaria cookii, Malachite green, Biosorption.

\section{INTRODUCTION}

Industrial wastewater containing dyes are frequently polluting freshwater ecosystems. The presence of colorants is of concern due to their toxicity and health effects on the human health and living creatures. Recent estimates indicate that, $12 \%$ of synthetic textile dyes used each year are lost during manufacture and processing operation and $20 \%$ of these dyes enter the environment through effluents that result from the treatment of residual industrial waters ${ }^{1}$. Malachite green (MG), is a cationic dye [Color Index (CI): 42000, chemical formula: $\mathrm{C}_{23} \mathrm{H}_{25} \mathrm{~N}_{2} \mathrm{Cl}$, formula weight (FW): $364.9 \mathrm{~g} \mathrm{~mol}^{-1}$ and absorbance maximum $\left(\lambda_{\max }\right): 617 \mathrm{~nm}$ ] which is widely used to color cotton, jute, silk, wool, leather and also extensively used in the fish farming industry as fungicide, ectoparasiticide and disinfectant all over the world ${ }^{2}$ The discharge of malachite green into receiving streams damages the aquatic life by causing detrimental effects in liver, gall, kidney, intestine, gonads and pituitary gonadotrophic cells. In humans, as a result of inhalation it may cause irritation to the respiratory tract and also causes irritation to the gastrointestinal tract upon ingestion. It is also highly toxic to mammalian cells and acts as a tumor enhancing agent ${ }^{3-5}$. For these reasons the removal of malachite green and other toxic dyestuffs from waters and wastewaters is attained by many researchers. Various techniques have been employed for the removal of dyes from wastewaters. These methods include adsorption, nanofiltration, electro kinetic coagulation, coagulation and precipitation, advanced chemical oxidation, electrochemical oxidation, ozonation, supported liquid membrane, liquid-liquid extraction and biological process $^{6}$. The adsorption process is one of the efficient methods to remove dyes from effluent due to its low initial cost, simplicity of design, ease of operation and insensitivity to toxic substances $^{7}$. Activated carbon is the most widely used adsorbent with great success due to its large surface area, microporous structure, high adsorption capacity, etc. However, its use is limited because of its high cost. This has led to research for cheaper substitutes ${ }^{8}$.

Many investigators have studied the feasibility of using inexpensive alternative materials like pearl millet husk, date pits, saw dust buffing dust of leather industry, coir pith, crude oil residue tropical grass, olive stone and almond shells, pine bark, wool waste, coconut shell etc., as carbonaceous precursors for the removal of dyes from water and wastewater'. However the adsorption capacities of the above adsorbents are not very high. In order to improve the efficiency of the adsorption processes, it is necessary to develop cheap and easily available adsorbents with high adsorption capacities. 
The objective of the present study is to evaluate the potential usage of Araucaria cookii bark (ACB) as a low cost adsorbent for the removal of one of the highly toxic dye, malachite green, from aqueous solutions. The effects of important experimental parameters such as contact time, initial malachite green concentration, adsorbent concentration, $\mathrm{pH}$ and temperature were studied. The adsorption mechanism of malachite green onto ACB was evaluated in terms of thermodynamics and kinetics. The adsorption isotherms were described by using the Langmuir, Freundlich and Tempkin isotherm models.

\section{EXPERIMENTAL}

The dye, malachite green was supplied by BALADA Chemicals, Visakhapatnam, India. The stock solution (1000 $\mathrm{mg} \mathrm{L}^{-1}$ ) of malachite green was prepared by dissolving accurately weighed amount of the dye in distilled water. All the chemicals used throughout this study were of analytical- grade. All working solutions of desired concentrations were obtained by diluting the stock solution with distilled water. The $\mathrm{pH}$ of the solutions was adjusted with $0.1 \mathrm{~mol} \mathrm{~L}^{-1} \mathrm{HCl}$ or $0.1 \mathrm{~mol} \mathrm{~L}^{-1}$ $\mathrm{NaOH}$.

Biosorbent preparation: Araucaria cookii bark was collected from the GMR Institute of Technology, Rajam, Andhrapradesh, India. The preparation of biosorbent was reported by Kalpana and King ${ }^{10}$.

Characterization: SEM analysis was carried out on the ACB to study its surface texture before and after malachite green biosorption. FTIR spectroscopy was used to identify the chemical present in the biosorbent. Infrared spectra of the samples (ACB before biosorption of malachite green) and the malachite green loaded samples were obtained using a FTIR spectrophotometer.

Experimental design by response surface methodology (RSM): The effect of various process parameters such as temperature $\left(\mathrm{x}_{1}\right), \mathrm{pH}\left(\mathrm{x}_{2}\right)$, dosage $\left(\mathrm{x}_{3}\right)$ and initial dye concentration $\left(\mathrm{x}_{4}\right)$ on color removal was studied by using central composite design (CCD). A CCD with 26 experiments was used for the optimization of process parameters for removal of malachite green dye from synthetic solution. All independent variables were coded to four levels as $\mathrm{X}_{\mathrm{i}}$ according to eqn. 1 .

$$
\mathrm{X}_{\mathrm{i}}=\frac{\mathrm{x}_{\mathrm{i}}-\mathrm{x}_{\mathrm{oi}}}{\Delta \mathrm{x}_{\mathrm{i}}}(\mathrm{i}=1,2,3, \ldots \mathrm{k})
$$

where $\mathrm{x}_{\mathrm{i}}$ is dimensional less value of an independent variable, $\mathrm{x}_{\mathrm{i}}$ is the real value of an independent variable, $\mathrm{x}_{\mathrm{oi}}$ is the real value of the independent variable at the center point and $\Delta \mathrm{x}_{\mathrm{i}}$ is step change.

A polynomial (eqn. 2) was developed to estimate the behaviour of the percentage removal of color.

$$
\begin{gathered}
Y=b_{0}+b_{1} x_{1}+b_{2} x_{2}+b_{3} x_{3}+b_{4} x_{4}+b_{11} x_{1}^{2}+b_{22} x_{2}^{2}+b_{33} x_{3}^{2} \\
+b_{44} x_{4}^{2}+b_{12} x_{1} x_{2}+b_{13} x_{1} x_{3}+b_{14} x_{1} x_{4}+b_{23} x_{2} x_{3}+b_{24} x_{2} x_{4} \\
+b_{34} x_{3} x_{4}
\end{gathered}
$$

where $\mathrm{Y}$ is the predicted response; $\mathrm{x}_{1}, \mathrm{x}_{2}, \mathrm{x}_{3}$ and $\mathrm{x}_{4}$ are independent variables; $b_{0}$ is an offset term; $b_{1}, b_{2}, b_{3}$ and $b_{4}$ are linear effects; $b_{11}, b_{22}, b_{33}$ and $b_{44}$ are squared effects and $b_{12}$, $b_{13}, b_{14}, b_{23}, b_{24}$ and $b_{34}$ are interaction terms.
Experimental procedure: Biosorption studies were mainly carried out by batch technique to obtain rate and equilibrium data. The experiments were performed to observe the effect of important parameters like initial $\mathrm{pH}(2,34,5,6,7,8$, $9,10,11)$, initial malachite green concentration $(20,40,60$, 80 and $100 \mathrm{mg} \mathrm{L}^{-1}$ ), biosorbent dosage (0.02, 0.04, 0.06, 0.08 and $0.1 \mathrm{~g}$ per $30 \mathrm{~mL}$ of synthetic solution), contact time (1-45 min) and temperature $(303,308,313,318,323 \mathrm{~K})$ on the adsorptive removal of malachite green. For each experimental run, $30 \mathrm{~mL}$ of malachite green solution of known concentration, $\mathrm{pH}$ and a known amount of the biosorbent were taken in a $100 \mathrm{~mL}$ stoppered conical flask. The mixture was agitated in a temperature controlled orbital shaker at a constant speed of $180 \mathrm{rpm}$ at $30 \pm 1^{\circ} \mathrm{C}$. Samples were withdrawn at appropriate time intervals. All the samples were centrifuged at $5000 \mathrm{rpm}$ for $10 \mathrm{~min}$ to settle down suspended particles. After centrifugation clear supernatant samples were obtained and their residual dye concentration was analyzed by using UV spectrophotometer. The above procedure was repeated for different $\mathrm{pH}$ values, initial dye concentration, dosage of biosorbent, contact time and temperatures. All experiments were performed triplicate and reported values are average of three. The percentage color removal of dye and dye uptake were calculated using the following relationships:

$$
\begin{gathered}
\text { Color removal }(\%)=\frac{\left(\mathrm{C}_{\mathrm{i}}-\mathrm{C}_{\mathrm{f}}\right)}{\mathrm{C}_{\mathrm{i}}} \times 100 \\
\text { Dye uptake }(\mathrm{q})=\left(\mathrm{C}_{\mathrm{i}}-\mathrm{C}_{\mathrm{f}}\right) \frac{\mathrm{v}}{\mathrm{m}}
\end{gathered}
$$

where $C_{i}$ is the initial sorbent concentration $(\mathrm{mg} / \mathrm{L}), \mathrm{C}_{\mathrm{f}}$ is the final sorbent concentration $(\mathrm{mg} / \mathrm{L}), \mathrm{v}$ is the volume of the solution $(\mathrm{L})$ and $\mathrm{m}$ is the mass of the biosorbent $(\mathrm{g})$.

\section{RESULTS AND DISCUSSION}

Biosorbent characterization: Fig. 1 shows the SEM micrographs of ACB sample before and after dye adsorption. It is clear that ACB has considerable numbers of heterogeneous layer of pores where there is a good possibility for dye to be adsorbed (Fig. 1a). The surface of dye-loaded adsorbent, however, clearly shows that the surface of ACB is covered with dye molecules (Fig. 1b).

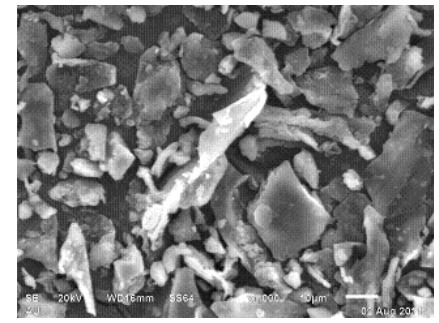

(a)

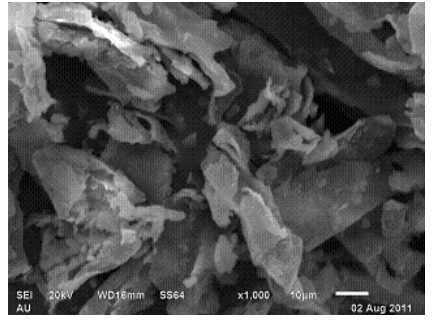

(b)
Fig. 1 (a) SEM of ACB-Raw, (b) SEM of malachite green loaded ACB

The FTIR spectrum of ACB (Fig. 2a and 2b) shows that some peaks were shifted or disappeared and those new peaks were also detected. These changes observed in the spectrum indicated the possible involvement of those functional groups on the surface of the ACB in adsorption process. 


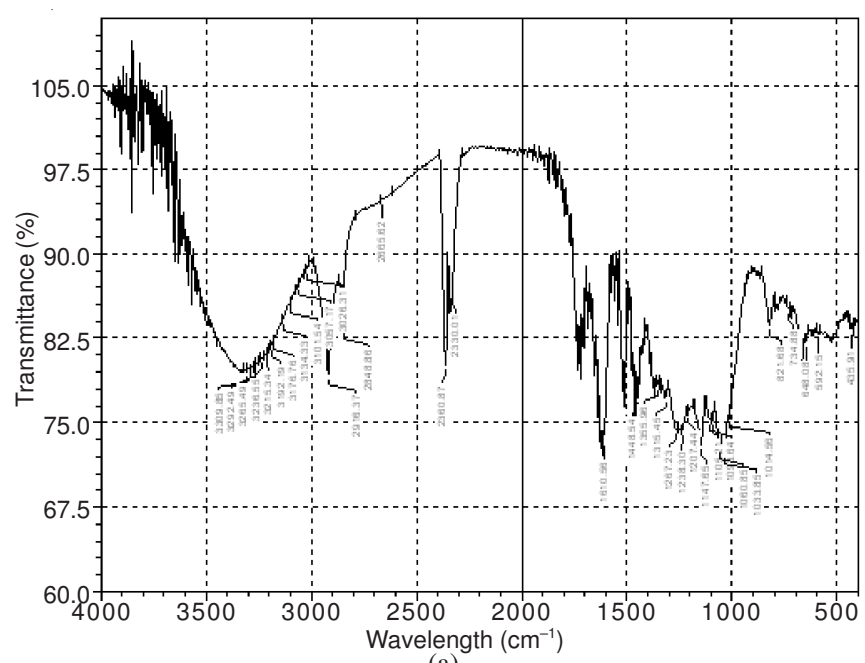

(a)

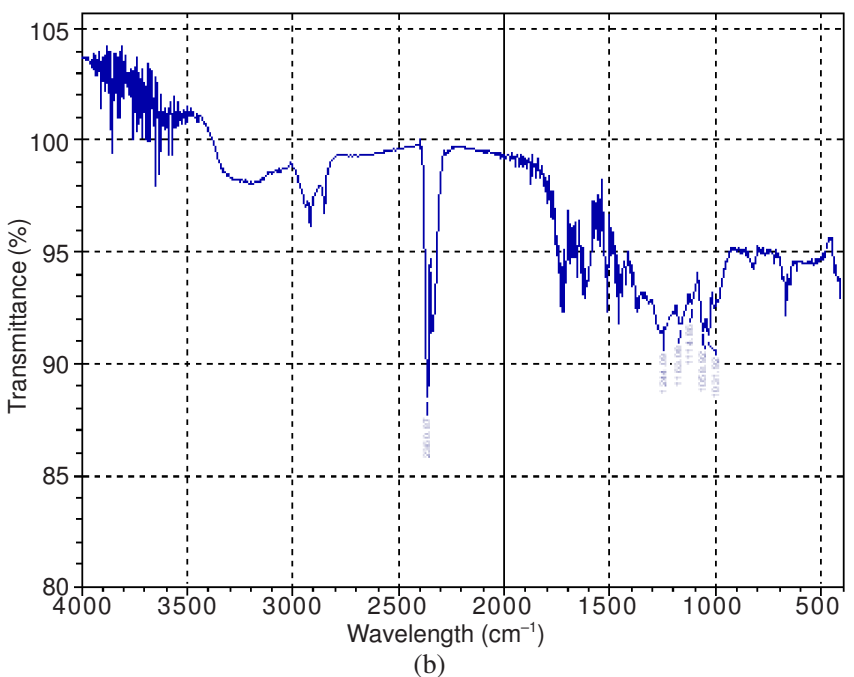

Fig. 2. (a) FTIR of ACB, (b) FTIR of ACB with malachite green

Experimental design and fitting of quadratic model: To examine the combined effect of four different process parameters, on percentage color removal of malachite green, 26 experiments were performed. Eqn. 5 represents the mathematical model relating the percentage color removal with the independent process variables. The second order polynomial coefficient for each term of equation was determined through multiple regression analysis using the Statistica 6.0. The experimental and predicted values of percentage biosorption of malachite green were given in Table-1.

\begin{tabular}{|c|c|c|c|c|c|c|}
\hline \multicolumn{7}{|c|}{$\begin{array}{c}\text { TABLE-1 } \\
\text { LEVELS OF DIFFERENT PROCESS VARIABLES USED } \\
\text { IN CENTRAL COMPOSITE DESIGN FOR REMOVAL } \\
\text { OF MALACHITE GREEN DYE }\end{array}$} \\
\hline \multirow{2}{*}{ Factor } & \multirow{2}{*}{ Symbol } & \multicolumn{5}{|c|}{ Level } \\
\hline & & -2 & -1 & 0 & +1 & +2 \\
\hline Temp. (K) & $\mathrm{x}_{1}$ & 30 & 35 & 40 & 45 & 50 \\
\hline $\mathrm{pH}$ & $\mathrm{x}_{2}$ & 1 & 2 & 3 & 4 & 5 \\
\hline Dosage (g) & $\mathrm{x}_{3}$ & 0.02 & 0.04 & 0.06 & 0.08 & 0.10 \\
\hline $\begin{array}{l}\text { Initial dye } \\
\text { conc. }(\mathrm{mg} / \mathrm{L})\end{array}$ & $\mathrm{x}_{4}$ & 20.00 & 40.00 & 60.00 & 80.00 & 100.00 \\
\hline
\end{tabular}

Color removal (\%), $\mathrm{Y}=-121.96+6.9 \mathrm{x}_{1}+28.71 \mathrm{x}_{2}+1150.17 \mathrm{x}_{3}$ $+0.23 \mathrm{x}_{4}-0.11 \mathrm{x}_{1}^{2}-4 \mathrm{x}_{2}^{2}-4872.04 \mathrm{x}_{3}^{2}+0.05 \mathrm{x}_{1} \mathrm{x}_{2}+0.78 \mathrm{x}_{2} \mathrm{x}_{3}+$ $0.91 \mathrm{x}_{3} \mathrm{x}_{4}$
The proposed model was evaluated by regression coefficients, standard error, $t$-values, $p$-values and correlation coefficient $\left(\mathrm{R}^{2}\right)$. The smaller the magnitude of the $\mathrm{P}$, the more significant is the corresponding coefficient. Values of $\mathrm{P}$ less than 0.05 indicate the model term is significant ${ }^{11}$. From the $\mathrm{P}$ values it was found that, among the test variables used in the study, $\mathrm{x}_{1}, \mathrm{x}_{2}, \mathrm{x}_{1}{ }^{2}$ and $\mathrm{x}_{2}{ }^{2}$ were significant model terms. These terms had more influence in comparison to the interaction terms. The predicted $\mathrm{R}^{2}$ of 0.9678 is in reasonable agreement with the adjusted $\mathrm{R}^{2}$ of 0.9269 . This implies that the prediction of experimental data is quite satisfactory.

Optimization of adsorption was done for target value of $96.1 \%$ efficiency of dye removal using response optimization process. The temperature $\left(33.97{ }^{\circ} \mathrm{C}\right), \mathrm{pH}(2.95)$, dosage $(0.098 \mathrm{~g})$ and initial dye concentration $(20.42 \mathrm{mg} / \mathrm{L})$ were found to be optimum conditions for maximum $96.1 \%$ dye removal by using ACB.

Influence of contact time: The effect of contact time for the removal of malachite green by the ACB at different concentrations for $0.1 \mathrm{~g}$ of biosorbent (Fig. 3) showed rapid adsorption of dye in the first $15 \mathrm{~min}$ and, thereafter, adsorption reached equilibrium. Further batch experiments were conducted for 15 min contact time with shaking speed of $180 \mathrm{rpm}$. A large number of vacant surface sites are available for adsorption during the initial stage and after a lapse of time, the remaining vacant surface sites are difficult to be occupied due to repulsive forces between the solute molecules on the solid and bulk phases $^{12-14}$.

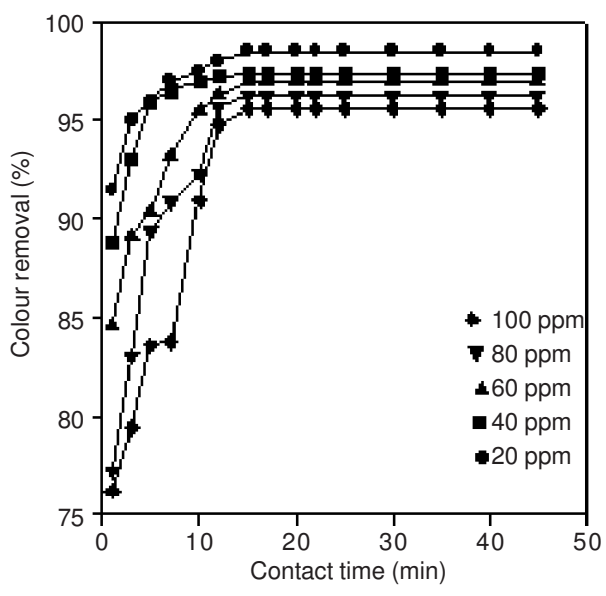

Fig. 3. Influence of contact time

Influence of solution pH: The initial $\mathrm{pH}$ of the dye solution is an important parameter, which controls the adsorption process particularly the adsorption capacity ${ }^{15}$. Fig. 4 shows the biosorption capacity of ACB increased from $\mathrm{pH} 1$ to 3 and reached maximum at $\mathrm{pH} 3$ and then declined sharply with further increase in $\mathrm{pH}$ indicating that the optimal $\mathrm{pH}$ for biosorption of ACB is 3 under the experimental conditions. The change pattern of the biosorption capacity with $\mathrm{pH}$ could be associated with the effect of $\mathrm{pH}$ on both the activity of functional groups of the biosorbent and the chemical properties of dyes ${ }^{16}$. Acidic conditions could be favourable for the biosorption between the malachite green and the ACB, because a significantly high electrostatic attraction could exist between the positively charged surface of the adsorbent under acidic 


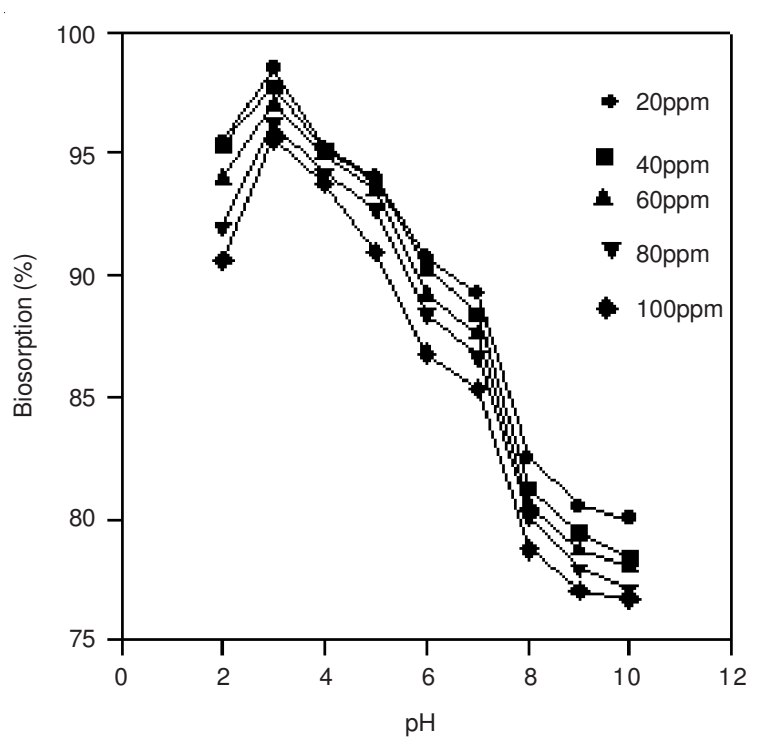

Fig. 4. Influence of $\mathrm{pH}$

conditions and the malachite green. At higher $\mathrm{pH}$ the percentage biosorption values were low. The low biosorption capacity under alkaline conditions could be mainly attributed to that the increasing number of negative charge on the surface of the ACB could result in electrostatic repulsion between the adsorbent and dye molecules ${ }^{17}$ and that the existence of excess $\mathrm{OH}^{-}$ions may compete with the cationinc dyes for the decreasing number of positively charged sites on the ACB as the $\mathrm{pH}$ increased. A similar trend was observed for the biosorption of Congo Red on Trametes versicolor ${ }^{18}$, coir pith carbon $^{19}$ and Penicillium YW $01^{16}$. Hence, acidic conditions were more favorable for the application of biosorption process of malachite green onto ACB biomass.

Influence of initial dye concentration: The effect of initial concentration on the removal of malachite green by ACB is shown in Fig. 5. It is evident from the figure that the amount of malachite green adsorbed per unit mass of ACB was increased with an increase in initial dye concentration, although percentage removal of malachite green was decreased with an increase in concentration. The initial concentration provides necessary driving force to overcome the resistances to the mass transfer of malachite green between the aqueous phase and the solid phase. The increase in initial concentration also enhances the interaction between malachite green and ACB. Therefore, an increase in initial dye concentration of malachite green enhances the adsorption uptake of malachite green. The rate of adsorption also increases with an increase in initial dye concentration due to increase in the driving force ${ }^{20}$. Similar trend was reported in literature for the removal of Brilliant Green by adsorbents like saw dust ${ }^{21}$, neem leaf powder ${ }^{22}$ and modified peat-resin particles ${ }^{23}$.

Influence of biosorbent dosage: Study of the effect of biosorbent dosage gives an idea of the effectiveness of a biosorbent and the ability of a dye to be adsorbed with a minimum dosage, so as to identify the ability of a dye from an economical point of view. Fig. 6 explains the influence of biosorbent dosage on \% color removal of malachite green. Usually the percentage of dye removal increases with an increase in biosorbent dosage, where the number of sorption

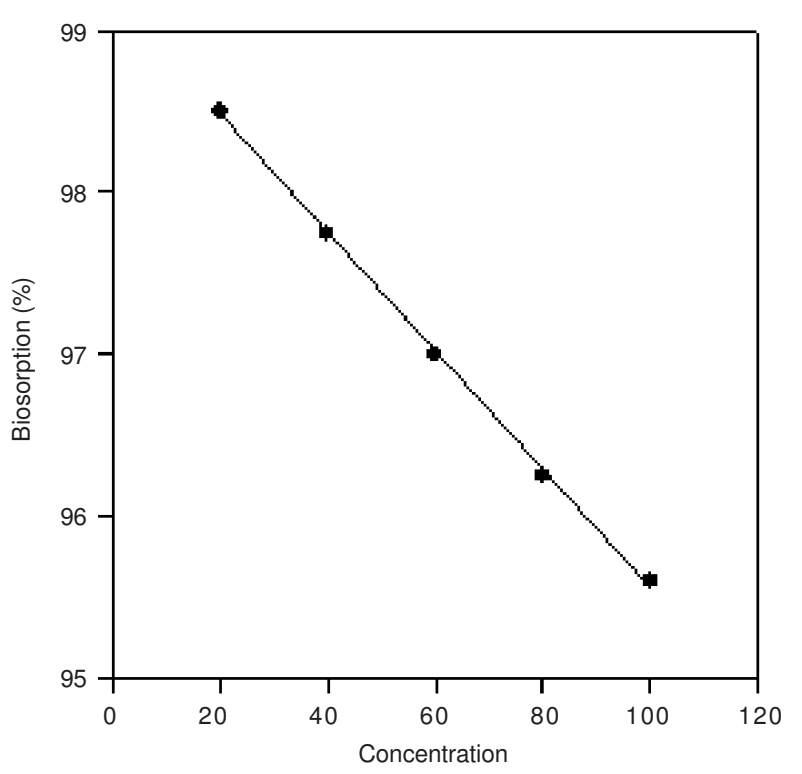

Fig. 5. Influence of concentration

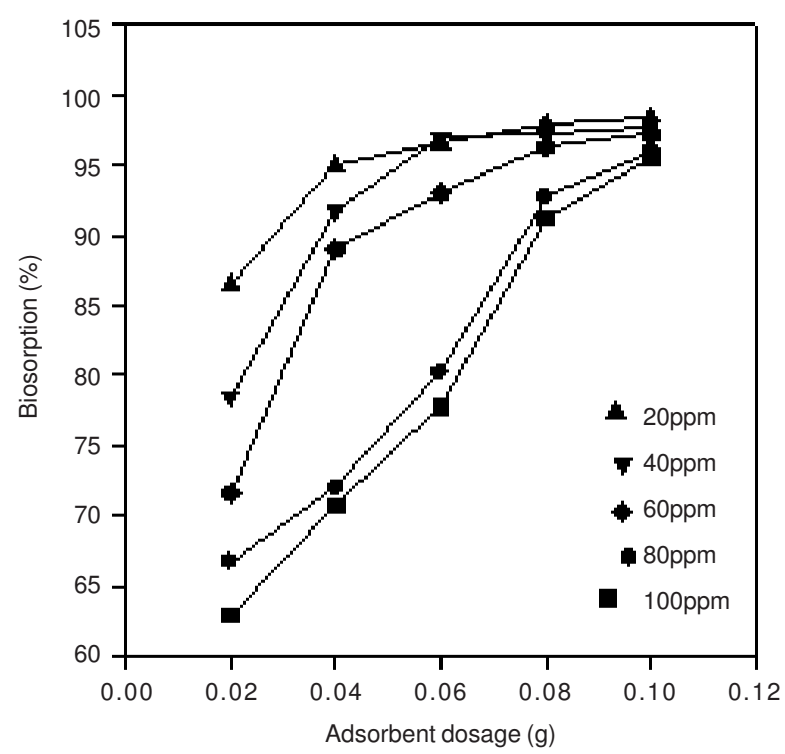

Fig. 6. Influence of dosage

sites at the adsorbent surface will increase by increasing the dosage of the adsorbent ${ }^{24}$ and as a result increase in the percentage of dye removal from the solution.

Influence of temperature: Fig. 7 shows the effect of temperature on the biosorption of malachite green onto ACB. The decrease in dye biosorption capacity with increasing temperature might be due to desorption of dye by ACB. Juang et al..$^{25}$ and others ${ }^{26}$ had reported similar results. The decrease in biosor-ption capacity with an increase in temperature, suggests the exothermic characteristic of the biosorption. For the adsorption, the process is usually a diffusion process with exothermic property. A higher temperature can result in an increase in the mobility of the dye ions but can decrease the interaction of dye with active sites of biosorbent. On the other hand, increasing temperature may produce a swelling effect within the internal structure of the ACB enabling malachite green to exit further from the pores. 


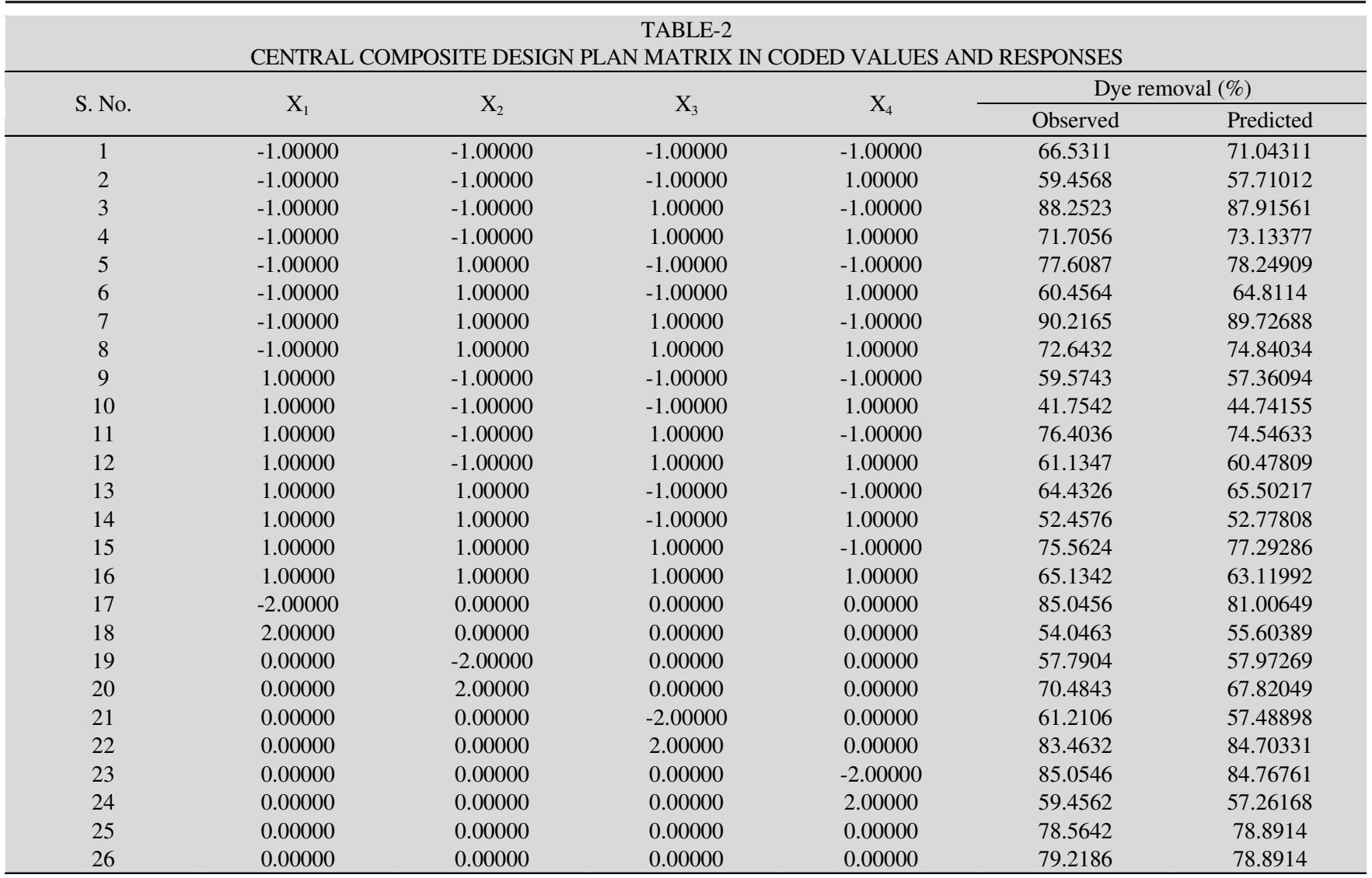

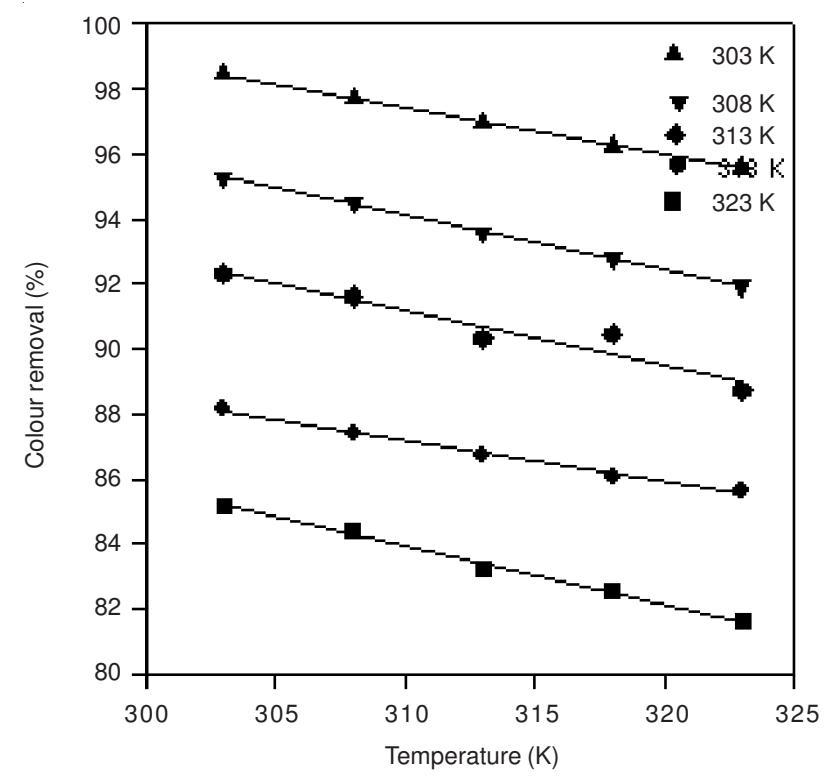

Fig. 7. Influence of temperature

Biosorption isotherms: To optimize the design of an adsorption system for the adsorption of adsorbates, it is important to establish the most appropriate correlation for the equilibrium curves ${ }^{27}$. Freundlich ${ }^{28}$, Langmuir ${ }^{29}$ and Tempkin isotherm equations have been used to describe the equilibrium nature of adsorption.

The linearized Freundlich and Langmuir isotherms are represented by the following equations:

Freundlich isotherm $\ln \mathrm{q}_{\mathrm{e}}=\ln \mathrm{k}_{\mathrm{F}}+\frac{1}{\mathrm{n}} \ln \mathrm{C}_{\mathrm{e}}$
TABLE-3

RESPONSE SURFACE REGRESSION OF PERCENTAGE COLOR REMOVAL OF MALACHITE GREEN

\begin{tabular}{ccccc}
\hline Term & Coefficient & Std. Error & t-Value & p-Level \\
\hline Constant & -121.96 & 71.224 & -1.71239 & 0.114833 \\
$\mathrm{X}_{1}$ & 6.90 & 2.701 & 2.55614 & 0.026702 \\
$\mathrm{X}_{2}$ & 28.71 & 8.968 & 3.20115 & 0.008437 \\
$\mathrm{X}_{3}$ & 1150.17 & 448.404 & 2.56502 & 0.026282 \\
$\mathrm{X}_{4}$ & 0.23 & 0.448 & 0.52147 & 0.612375 \\
$\mathrm{X}_{1}{ }^{2}$ & -0.11 & 0.032 & -3.31497 & 0.002166 \\
$\mathrm{X}_{2}{ }^{2}$ & -4.00 & 0.798 & -5.00862 & 0.000397 \\
$\mathrm{X}_{3}{ }^{2}$ & -4872.04 & 1995.912 & -2.44101 & 0.032764 \\
$\mathrm{X}_{4}{ }^{2}$ & 0.00 & 0.002 & -2.46653 & 0.031314 \\
$\mathrm{X}_{1}{ }^{*} \mathrm{X}_{2}$ & 0.05 & 0.167 & 0.28040 & 0.784377 \\
$\mathrm{X}_{1} * \mathrm{X}_{3}$ & 0.78 & 8.339 & 0.09381 & 0.926947 \\
$\mathrm{X}_{1}{ }^{*} \mathrm{X}_{4}$ & 0.00 & 0.008 & 0.21394 & 0.834505 \\
$\mathrm{X}_{2}{ }^{*} \mathrm{X}_{3}$ & -67.43 & 41.693 & -1.61738 & 0.134088 \\
$\mathrm{X}_{2}{ }^{*} \mathrm{X}_{4}$ & 0.00 & 0.042 & -0.03139 & 0.975521 \\
$\mathrm{X}_{3}{ }^{*} \mathrm{X}_{4}$ & -0.91 & 2.085 & -0.43438 & 0.672412 \\
\hline
\end{tabular}

$$
\text { Langmuir isotherm } \frac{\mathrm{C}_{\mathrm{e}}}{\mathrm{q}_{\mathrm{e}}}=\frac{1}{\mathrm{k}_{\mathrm{L}} \mathrm{q}_{\mathrm{m}}}+\frac{\mathrm{C}_{\mathrm{e}}}{\mathrm{q}_{\mathrm{m}}}
$$

where $\mathrm{k}_{\mathrm{f}}$ is Freundlich constant $(\mathrm{L} / \mathrm{mg}), 1 / \mathrm{n}$ is the heterogeneity factor, $\mathrm{K}_{\mathrm{L}}$ is the Langmuir adsorption constant $(\mathrm{L} / \mathrm{mg})$ related to energy of adsorption and $\mathrm{q}_{\mathrm{m}}$ signifies adsorption capacity (mg/g).

The linearized form of tempkin isotherm equation is

$$
\mathrm{q}_{\mathrm{e}}=\mathrm{A} \ln \mathrm{K}_{\mathrm{T}}+\mathrm{A} \ln \mathrm{C}_{\mathrm{e}}
$$

where $\mathrm{A}=\mathrm{RT} / \mathrm{b}, \mathrm{K}_{\mathrm{T}}$ is the equilibrium binding constant (L/mol) corresponding to the maximum binding energy and constant A is related to the heat of adsorption. The linearized Langmuir, Freundlich and Temkin adsorption isotherms obtained at room temperature are shown in Fig. 8. The calculated 


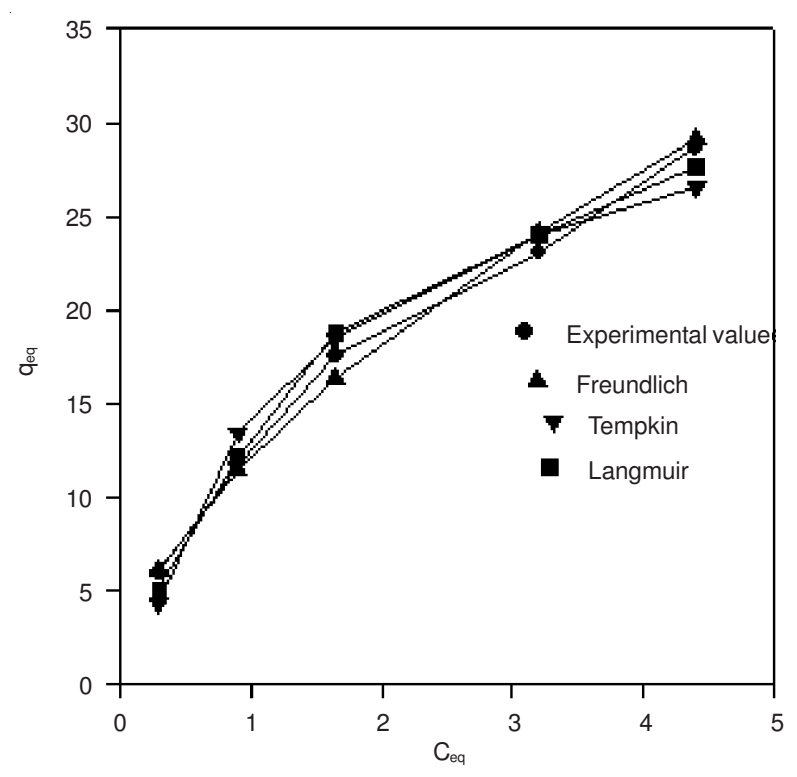

Fig. 8. Equilibrium curves

results of the Langmuir, Freundlich and Temkin isotherm constants are given in Table-4. Analysis on $r^{2}$ values from Table-4 shows that Freundlich equation was found to be best representing the equilibrium data for malachite green-ACB system.

\begin{tabular}{|c|c|c|}
\hline \multicolumn{3}{|c|}{$\begin{array}{l}\text { TABLE-4 } \\
\text { ADSORPTION ISOTHERMS AND CORRESPONDING } \\
\text { PARAMETERS FOR MG BINDING BY ACB }\end{array}$} \\
\hline Langmuir model & Freundlich model & Tempkin model \\
\hline $\mathrm{q}_{\mathrm{m}}=40.98$ & $\mathrm{n}=0.7041$ & $\mathrm{~b}_{\mathrm{T}}=305.68$ \\
\hline $\begin{array}{c}\mathrm{k}_{\mathrm{L}}=0.47 \\
\mathrm{r}^{2}-0.0716\end{array}$ & $\mathrm{~K}_{\mathrm{f}}=12.19$ & $\mathrm{~K}_{\mathrm{T}}=5.6965$ \\
\hline
\end{tabular}

Biosorption kinetics: The dynamics of the adsorption can be studied by the kinetics of adsorption in terms of the order of the rate constant ${ }^{30}$. The adsorption rate is an important factor for a better choice of material to be used as an adsorbent; where the adsorbent should have a large adsorption capacity and a fast adsorption rate. In order to investigat the biosorption process of malachite green on ACB, pseudo first order and pseudo second order kinetic models were used. The linear form of pseudo first order equation ${ }^{31}$ is

$$
\ln \left(\mathrm{q}_{\mathrm{e}}-\mathrm{q}\right)=\ln \left(\mathrm{q}_{\mathrm{e}}\right)-\mathrm{k}_{\mathrm{I}} \mathrm{t}
$$

where $\mathrm{q}_{\mathrm{e}}$ is the biosorption capacity in equilibrium $(\mathrm{mg} / \mathrm{g}), \mathrm{q}$ is the amount of adsorbate adsorbed at time $\mathrm{t}(\mathrm{mg} / \mathrm{g}), \mathrm{k}_{\mathrm{I}}$ is the rate constant of pseudo first order model $\left(\mathrm{min}^{-1}\right)$ and $t$ is the time (min). Values of $\mathrm{q}_{\mathrm{e}}$ and $\mathrm{k}_{\mathrm{I}}$ were determined from the plot of $\ln \left(\mathrm{q}_{\mathrm{e}}-\mathrm{q}\right)$ against $\mathrm{t}$ (Fig. 9). These values (Table-5) indicate that the adsorption rate was very fast at the beginning.

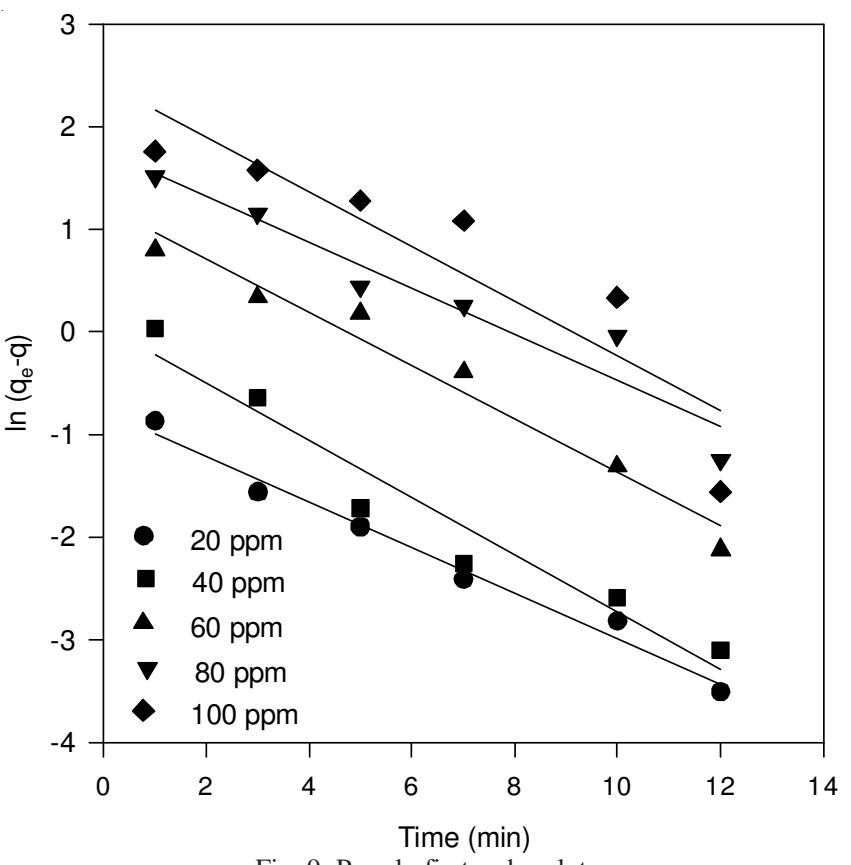

Fig. 9. Pseudo first order plot

The linear form of pseudo second order equation ${ }^{32}$ is

$$
\frac{\mathrm{t}}{\mathrm{q}}=\frac{1}{\mathrm{k}_{\mathrm{II}} \mathrm{q}_{\mathrm{e}}^{2}}+\frac{1}{\mathrm{q}_{\mathrm{e}}} \mathrm{t}
$$

The equilibrium adsorption capacity $\left(\mathrm{q}_{\mathrm{e}}\right)$ and the pseudo second order contant $\mathrm{k}_{\mathrm{II}}$ can be determined experimentally from the slope and intercept plot of t/q versus $\mathrm{t}$ (Fig. 10). Since calculated correlation coefficients are closer to unity for pseudo second order kinetic model than the pseudo first order kinetic model, the adsorption kinetics could well be approximated more favorably by pseudo second order kinetic model for malachite green dye. The reaction rate constant and correlation coefficient values are given in Table- 5 .

Biosorption thermodynamics: To estimate the effect of temperature on the biosorption of malachite green onto ACB, the Gibbs free energy change $\left(\Delta \mathrm{G}^{\mathrm{o}}\right)$, enthalpy change $\left(\Delta \mathrm{H}^{\circ}\right)$ and entropy change $\left(\Delta \mathrm{S}^{\circ}\right)$ were determined from the slope and intercept of the van't Hoff plot of ln K versus 1/T (Fig. 11). Table presents the thermodynamic parameters at various temperatures. The negative $\Delta \mathrm{G}^{\mathrm{o}}$ values indicate that the biosorption process is feasible and the adsorption process is spontaneous in nature. The value of $\Delta \mathrm{G}^{\mathrm{o}}$ was found to increase in the temperature range of $303-323 \mathrm{~K}$, indicating that the biosorption process of malachite green on $\mathrm{ACB}$ becomes more favorable at lower temperatures. $\Delta \mathrm{H}^{\circ}$ and $\Delta \mathrm{S}^{\circ}$ were calculated as $-95.94 \mathrm{KJ} / \mathrm{mol}$ and $294.3 \mathrm{~J} / \mathrm{mol}$, respectively. The negative value of $\Delta \mathrm{H}^{\circ}$ implies the exothermic nature of the biosorption process. In an exothermic process, the total energy absorbed

TABLE-5

\begin{tabular}{|c|c|c|c|c|c|c|c|c|c|c|}
\hline \multirow{2}{*}{ Initial conc. $(\mathrm{mg} / \mathrm{L})$} & \multicolumn{2}{|c|}{20} & \multicolumn{2}{|c|}{40} & \multicolumn{2}{|c|}{60} & \multicolumn{2}{|c|}{80} & \multicolumn{2}{|c|}{100} \\
\hline & $\mathrm{k}_{\mathrm{I}}$ & $\mathrm{k}_{\mathrm{II}}$ & $\mathrm{k}_{\mathrm{I}}$ & $\mathrm{k}_{\mathrm{II}}$ & $\mathrm{k}_{\mathrm{I}}$ & $\mathrm{k}_{\mathrm{II}}$ & $\mathrm{k}_{\mathrm{I}}$ & $\mathrm{k}_{\mathrm{II}}$ & $\mathrm{k}_{\mathrm{I}}$ & $\mathrm{k}_{\mathrm{II}}$ \\
\hline Rate constant & 0.222 & 1.235 & 0.2785 & 0.561 & 0.260 & 0.1766 & 0.224 & 0.083 & 0.266 & 0.045 \\
\hline $\mathrm{q}(\mathrm{calc})$ & 0.464 & 5.96 & 1.0535 & 11.84 & 3.425 & 17.83 & 5.856 & 23.84 & 0.087 & 30.03 \\
\hline$q($ expt $)$ & 5.91 & 5.91 & 11.45 & 11.45 & 17.51 & 17.51 & 23.04 & 23.04 & 28.68 & 28.68 \\
\hline $\mathrm{R}^{2}$ & 0.982 & 0.999 & 0.9425 & 0.9999 & 0.977 & 0.999 & 0.928 & 0.999 & 0.813 & 0.999 \\
\hline
\end{tabular}

PARAMETERS OF PSEUDO FIRST ORDER AND PSEUDO SECOND ORDER MODEL 


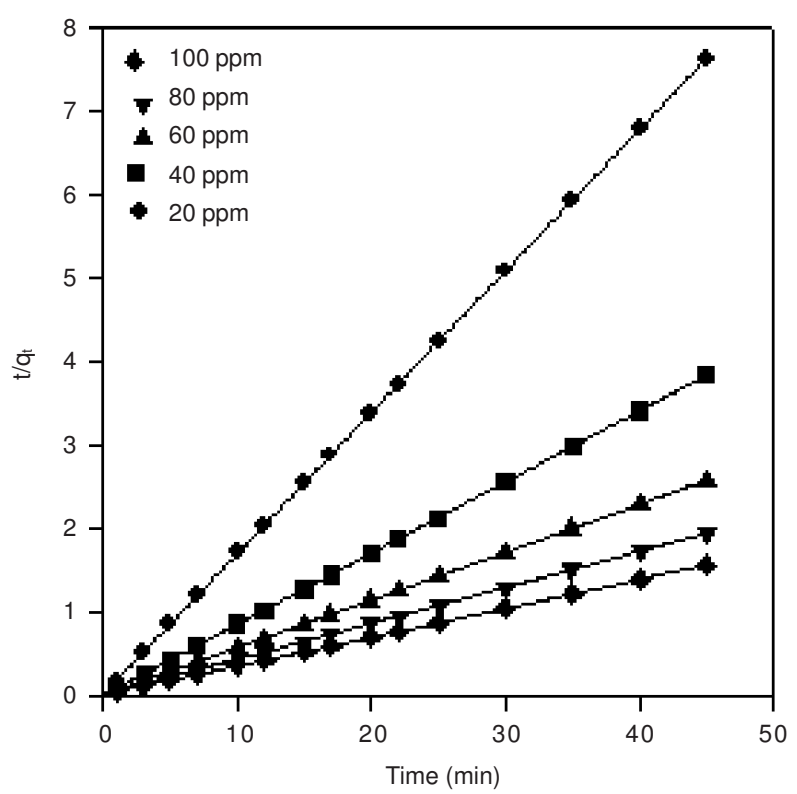

Fig. 10. Pseudo second order plot

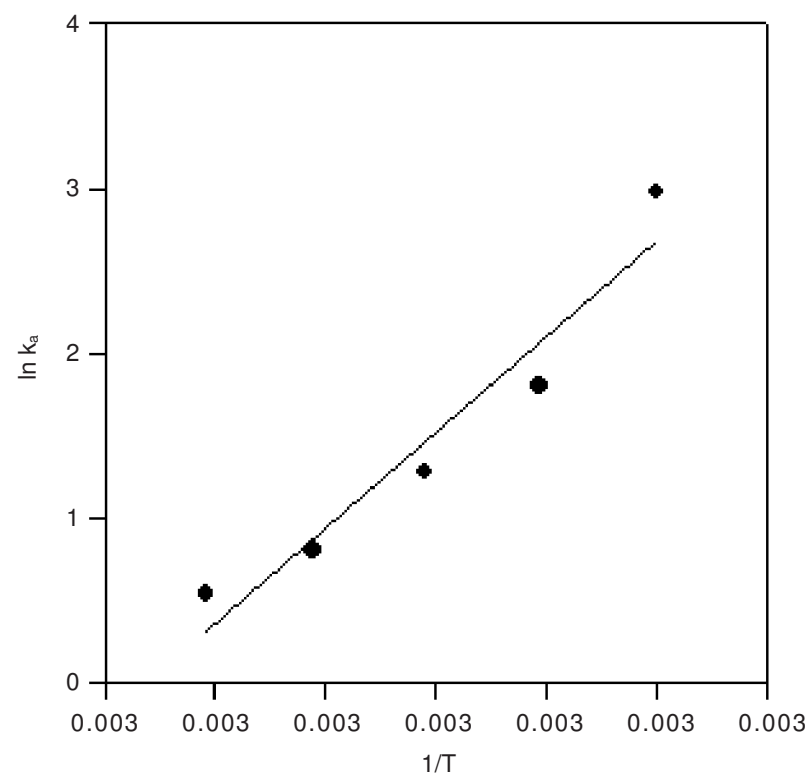

Fig. 11. Plot of $\ln \mathrm{k}_{\mathrm{a}}$ versus $1 / \mathrm{T}$

in bond breaking is less than the total energy released in bond making between adsorbate and adsorbent, resulting in the release of extra energy in the form of heat.

\section{Conclusion}

This work has proved that ACB can be employed as effective biosorbent for removal of malachite green. The improved biosorption capacity can reach to $70.7 \mathrm{mg} / \mathrm{g}$ with maximum percentage of color removal 98.5 for initial malachite green concentration of $20 \mathrm{mg} / \mathrm{L}, \mathrm{ACB}$ dosage of $3.3 \mathrm{~g} / \mathrm{L}$, biosorption temperature of $30^{\circ} \mathrm{C}$, the initial $\mathrm{pH} 3$ and optimum contact time $15 \mathrm{~min}$ using batch experimentation. Optimized parameters like temperature, $\mathrm{pH}$, dosage and initial dye concentration using response surface methodology were found to be $33.97{ }^{\circ} \mathrm{C}, 2.95,0.098 \mathrm{~g}$ and $20.42 \mathrm{mg} / \mathrm{L}$. Adsorption equilibrium is consistent with Freundlich model and the adsorption kinetics fits the pseudo second order equation, indicating that the adsorption is interaction rather than diffusioncontrolled. Thermodynamic analysis of the adsorption suggests that the process is exothermic and spontaneous as well as predominant in chemisorption.

\section{REFERENCES}

1. K. Selvarani, Ph.D. Thesis, Regional Engineering College, Tiruchirapalli, India (2000).

2. R. Gong, Y. Jin, F. Chen, J. Chen and Z. Liu, J. Hazard. Mater., 137, 865 (2006).

3. E. Bulut, M. Ozacar and I.A. Sengil, Micropor. Mesopor. Mater., 115, 234 (2008).

4. S. Srivastava, R. Sinha and D. Roy, Aquat. Toxicol., 66, 319 (2004).

5. J. Chen, J. Mao, X. Mo, J. Hang and M. Yang, Colloid Surf. A, 345, 231 (2009).

6. A.S. Mahmoud, A.E. Ghaly and M.S. Brooks, Am. J. Environ. Sci., 3, 205 (2007).

7. T. Robinson, G. McMullan, R. Marchant and P. Nigam, Bioresour. Technol., 77, 247 (2001).

8. S.J. Allen and B. Koumanova, J. Univ. Chem. Technol. Metallurgy, 40, 175 (2005).

9. G. Sekaran, K.A. Shanmugasundaram, M. Mariappan and K.V. Raghavan, Indian J. Chem. Technol., 2, 311 (1995).

10. P. Kalpana and P. King, Int. J. Waste Water Treatment Green Chem., 2, 31 (2011).

11. H.K. Kim, J.G. Kim, J.D. Cho and J.W. Hong, Polym. Test., 22, 899 (2003).

12. B.K. Nandi, A. Goswami and M.K. Purkait, J. Hazard. Mater., 161, 387 (2009).

13. M.H. Kalavathy and L.R. Miranda, Desalination, 255, 165 (2010).

14. V.C. Srivastava, I.D. Mall and I.M. Mishra, Colloids Surf. A, 312, 172 (2008).

15. B.K. Nandi, A. Goswami and M.K. Purkait, J. Hazard. Mater., 161, 387 (2009).

16. Y. Yang, G. Wang, B. Wang, Z. Li, X. Jia, Q. Zhou and Y. Zhao, Bioresour. Technol., 102, 828 (2011).

17. Z. Aksu and G. Donmez, Chemosphere, 50, 1075 (2003).

18. A.R. Binupriya, M. Sathishkumar, K. Swaminathan, C.S. Ku and S.E. Yun, Bioresour. Technol., 99, 1080 (2008).

19. C. Namasivayam and D. Kavitha, Dyes Pigments, 54, 47 (2002).

20. M.H. Kalavathy and L.R. Miranda, Desalination, 255, 165 (2010).

21. V.S. Mane and P.V.V. Babu, Desalination, 273, 321 (2011).

22. K.G. Bhattacharya and A. Sharma, Dyes Pigments, 57, 211 (2003).

23. Q. Sun and L. Yang, Water Res., 37, 1535 (2003).

24. A.E. Ofomaja, Biochem. Eng. J., 40, 8 (2008).

25. L.-Ch. Juang, Ch.-C. Wang and Ch.-K. Lee, Chemosphere, 64, 1920 (2006).

26. Sh. Sohrabnezhad and A. Pourahmad, Desalination, 256, 84 (2010).

27. I.D. Mall, V.C. Srivastava and N.K. Agarwal, Dyes Pigments, 69, 210 (2006).

28. H. Freundlich, J. Phys. Chem., 40, 857 (1936).

29. I. Langmuir, J. Am. Chem. Soc., 40, 1361 (1918).

30. V. Gómez, M.S. Larrechi and M.P. Callao, Chemosphere, 69, 1151 (2007).

31. S. Lagergren, K. Sven. Vetenskapsakad. Handl., 24, 1 (1898).

32. Y.S. Ho and G. McKay, Process Safety Environ. Protection, 76(B2), 183 (1998) 